\title{
Pengembangan Arsitektur Bisnis Sekolah Menggunakan Analisis Semantik
}

\author{
Eka Sifatul Fitri', Anisatul Mukaromah ${ }^{2}$, Risky Aprilia Wahyunigsih ${ }^{3}$, Muhammad Ainul \\ Yaqin 4 \\ 1,2,3,4Teknik Informatika, Universitas Islam Negeri Maulana Malik Ibrahim Malang \\ Jl. Gajayana No.50, Dinoyo, Kec. Lowokwaru, Kota Malang, Jawa Timur 65144 - Indonesia. \\ Telp. (0341) 531133. Fax. (0341) 531130 \\ 1ekasft7@gmail.com, 2anisatulstd15@gmail.com, 3kiki.riski04@gmail.com, 4yaqinov@ti.uin- \\ malang.ac.id
}

\begin{abstract}
Education in Indonesia must have standards in accordance with the provisions of Badan Standar Nasional Pendidikan to ensure the quality of education. Standar Nasional Pendidikan (SNP) is the education system criteria in Indonesia. SNP is as a reference for curriculum development, education staff, infrastructure, management and financing. SNP is useful for basic planning, implementation, and supervision of education in realizing national education for create an integrated system, methods needed in planning, managing and managing information systems called Enterprise Architecture. Development of enterprise architecture is modeled by the TOGAF (Open Group Architecture Framework) method that is Business Architecture phase. The research used in this Business Architecture is Bottom-Up, which starts the research from the bottom to the up starting from the Standard Operating Procedure (SOP), grouping Job Descriptions using the TF-IDF algorithm, until create an Organizational Structure.
\end{abstract}

Keywords: enterprise architechture, School, SNP,TOGAF, TF-IDF.

\begin{abstract}
Abstrak
Sekolah di Indonesia harus memiliki standar pendidikan yang sesuai dengan ketetapan Badan Standar Nasional Pendidikan untuk menjamin kualitas pendidikannya. Standar Nasional Pendidikan (SNP) adalah kriteria sistem pendidikan di Indonesia. SNP adalah sebagai rujukan dari pengembangan kurikulum, tenaga kependidikan, sarana prasarana, pengelolaan, dan pembiayaan. SNP berguna untuk dasar perencanaan, pelaksanaan, dan pengawasan pendidikan dalam mewujudkan pendidikan nasional bermutu Untuk membuat sistem yang terintegrasi, diperlukan metode dalam merencanakan, mengelola dan merancang sistem informasi yang disebut arsitektur enterprise. Pengembangan arsitektur enterprise dimodelkan dengan metode TOGAF (The open Group Architecture Framework) fase Arsitektur bisnis. Penelitian yang digunakan pada Arsitektur Bisnis ini adalah Bottom-Up, yaitu memulai penelitian dari urutan bawah ke urutan atas dimulai dari Standar Operasional Prosedur (SOP), pengelompokan Job Description menggunakan algoritma TF-IDF, hingga pembuatan Struktur Organisasi.
\end{abstract}

Kata kunci: arsitektur bisnis, sekolah,SNP, TOGAF, TF-IDF.

\section{PENDAHULUAN}

Sekolah merupakan salah satu organisasi yang bergerak di bidang layanan pendidikan [1]. Saat ini sekolah belum banyak menerapkan teknologi informasi dalam proses bisnis. Ada beberapa sekolah menggunakan teknologi informasi, namun untuk penerapannya dalam teknologi informasi masih kekurangan karena terintegrasinya sistem yang diterapkan dalam mendukung proses bisnis. Salah satu proses bisnis tersebut adalah arsitektur bisnis. Arsitektur Bisnis dapat menggambarkan kumpulan aktivitas bisnis, data dan informasi dalam lingkungan internal dan eksternal pada organisasi sekolah. Mengambangkan arsitektur bisnis 
sekolah penting dalam mengintegrasikan sistem antara bagian dalam organisasi dan referensi bagi manajemen dalam mengambil keputusan sebagai pendukung proses bisnis suatu organisasi. Arsitektur bisnis sekolah juga dapat meningkatkan sistem informasi dan mengembangkan sistem baru yang dapat mengoptimalkan nilai misi sekolah.

Keunggulan mengembangkan arsitektur bisnis sekolah dapat menyediakan mekanisme yang memungkinkan komunikasi tentang elemen proses bisnis di antara organisasi bisnis. Menghasilkan informasi terpusat, stabil, dan konsisten. Akses, dan pembagian informasi yang dikelola berkualitas dan realtime. Tersedianya arsitektur bisnis dapat mempermudah untuk mengambil keputusan agar lebih baik. Menghubungkan teknologi kepada misi organisasi sekolah, Mengurangi biaya sehingga lebih ekonomis, Meningkatkan keamanan.

Standar Nasional Pendidikan (SNP) adalah kriteria sistem pendidikan di Indonesia. SNP adalah sebagai rujukan dari pengembangan kurikulum, tenaga kependidikan, sarana prasarana, pengelolaan, dan pembiayaan. SNP berguna untuk dasar perencanaan, pelaksanaan, dan pengawasan pendidikan dalam mewujudkan pendidikan nasional bermutu. Di Indonesia ada beberapa sekolah yang belum memiliki struktur organisasi sekolah yang mengcover seluruh SNP yang ada. Hanya menerapkan beberapa SNP yang disebutkan diatas dan rata-rata proses bisnis sekolah yang dikelola kurang berjalan dengan baik. Agar proses bisnis sekolah berjalan dengan baik, perlu menerapkan seluruh SNP [2].

Untuk menerapkanya maka harus dibuat desain arsitektur dengan kerangka kerja khusus untuk merealisasikan kebutuhan akan sistem yang efektif dan efisien, itu dapat menggunakan Kerangka dalam bentuk The Open Group Architecture Framework (TOGAF). Kerangka kerja TOGAF menyediakan metode terperinci tentang cara membangun, mengelola, dan menerapkan kerangka kerja dan sistem informasi yang disebut Arsitecture Development Methode (ADM), yang dapat dibuat pada pengembangan sistem terintegrasi.

TOGAF ADM sebagai standar dalam pengembangan arsitektur enterprise karena TOGAF ADM merupakan metode yang kompleks dan mudah di implementasikan di industri akademik. Sehingga didapatkan gambaran yang jelas bagaimana melakukan perancangan arsitektur enterprise yang baik dan sesuai dengan organisasi [3]. Pada pembuatan arsitektur bisnis ini mengacu pada 8 standar nasional pendidikan. Dari 8 standar pendidikan, masing-masing akan dibuat SOP lalu dikelompokkan masing-masing SOP menggunakan algoritma TFIDF untuk memudahkan proses pengelompokkan SOP sehingga di dapatkan sebuah struktur organisasi dari sekolah.

\section{METODOLOGI PENELITIAN}

Data yang dibutuhkan dalam pengembangan arsitektur bisnis sekolah berupa Standar Nasional Pendidikan yang ditetapkan oleh BSNP (Badan Standar Nasional Pendidikan). Berikut 8 Standar Nasional Pendidikan di Indonesia

a) Standar Isi

b) Standar kompetensi Lulusan

c) Standar Proses Pendidikan 
https://tunasbangsa.ac.id/ejurnal/index.php/jurasik

d) Standar Sarana dan Prasarana

e) Standar Pengelolaan

f) Standar Pembiayaan Pendidikan

g) Standar Penilaian Pendidikan

h) Standar Pendidik dan Tenaga Kependidikan Instrumen pengumpulan data [4].

Data yang diambil pada penelitian ini adalah data sekunder yang menggunakan metode studi literatur. Metode ini dilakukan dengan cara mengumpulkan data dan informasi dari penelitian terkait sebelumnya dan dari berbagai sumber seperti jurnal, buku, serta artikel yang terkait dengan penelitian. Kemudian data yang telah ada dikelompokkan berdasarkan tahapan-tahapan TOGAF

\subsection{Prosedur Penelitian}

Prosedur penelitian menjelaskan bagaimana pelaksanaan penelitian.Tahapan penelitian yang dilakukan adalah sebagai berikut:

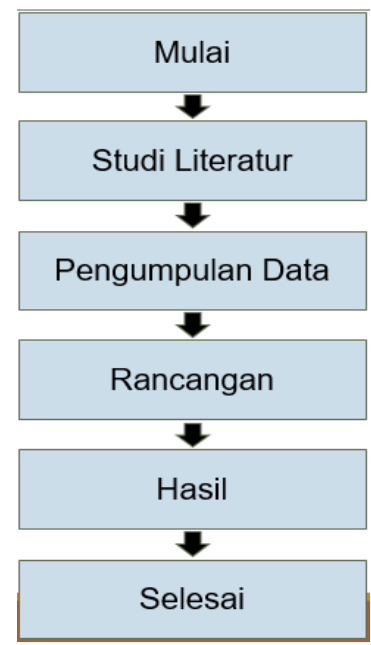

a. Pengumpulan Data

Gambar 1. Tahap Penelitian

Data yang dibutuhkan dalam pengembangan arsitektur bisnis sekolah berdasarkan kebutuhan sekolah dalam memanfaatkan IT secara maksimal sehingga dapat berjalan lebih efektif dan cepat dalam mengambil keputusan. Data yang diambil pada penelitian ini adalah data sekunder yang menggunakan metode kulitatif karena menganalisis kebutuhan sekolah berdasarkan 8 standar nasional pendidikan SNP. Metode ini dilakukan dengan cara mengumpulan data dan informasi dari penelitian terkait sebelumnya dan dari berbagai sumber seperti jurnal, buku, serta artikel yang terkait dengan penelitian.

b. Analisis Data

Analisis data pada penelitian ini yaitu analisis dari 8 standar nasional pendidikan untuk dijadikan sebuah Standar Operasional Prosedur (SOP) yang 
digunakan sebagai acuan dalam pembuatan model proses setiap proses bisnis yang ada pada sekolah.

c. Perancangan Proses Bisnis

Perancangan proses bisnis dalam penelitian ini yaitu membuat proses bisnis pada sekolah yang sesuai dengan 8 standar nasional pendidikan berdasarkan standar operasioanl prosedur (SOP) dari setiap proses bisnis/kegiatan yang terdapat dalam sekolah. Didalam proses bisnis berisi tentang kejadian-kejadian yang dilakukan mulai awal hingga akhir terjadinya suatu proses bisnis atau kegiatan.

d. Pengujian

Pengujian yang dilakukan dalam penelitian ini yaitu dengan mengujikan setiap proses bisnis yang telah dibuat untuk di implementasikan pada proses bisnis sekolah. Pengujian ini dilakukan untuk mengetahui seberapa efektif dan efisien proses bisnis sekolah, serta bagaimana dampak perubahan proses bisnis yang ada pada sekolah sebelum dan setelah terbentuknya model proses bisnis.

\subsection{Enterprise Arsitektur}

Definisi Arsitektur Perusahaan, seperti:

a. Representasi deskriptif (model) yang relevan untuk menggambarkan suatu perusahaan dan apa yang harus diproduksi untuk memenuhi kebutuhan manajemen atau organisasi [1].

b. Mapping Pemetaan cetak biru yang menunjukkan hubungan antara komponen dan semua orang yang bekerja di perusahaan secara konsisten untuk meningkatkan kerjasama / kolaborasi, dan koordinasi di antara mereka.

c. Sebuah mekanisme untuk memastikan sumber daya teknologi informasi dari suatu organisasi mungkin sejalan dengan strategi organisasi.

\subsection{TOGAF}

TOGAF (The Open Group Architecture Framework) adalah kerangka kerja arsitektur yang menyediakan metode dan alat lengkap untuk membantu dalam penerimaan, produksi, penggunaan, dan pemeliharaan arsitektur perusahaan [1].

\subsection{Metode TOGAF ADM}

Arsitektur Metode Pengembangan (ADM) logika metodologi TOGAF, yang terdiri dari delapan fase utama untuk pengembangan dan pemeliharaan arsitektur teknis organisasi. ADM untuk membentuk siklus berulang untuk seluruh proses, antara fase, dan di setiap fase di mana pada setiap iterasi keputusan baru harus diambil. Keputusan itu dimaksudkan untuk menentukan sejauh mana ruang lingkup perusahaan, tingkat detail, target waktu yang ingin dicapai dan aset arsitektur yang akan digali di perusahaan [5]. 


\subsection{Bottom Up}

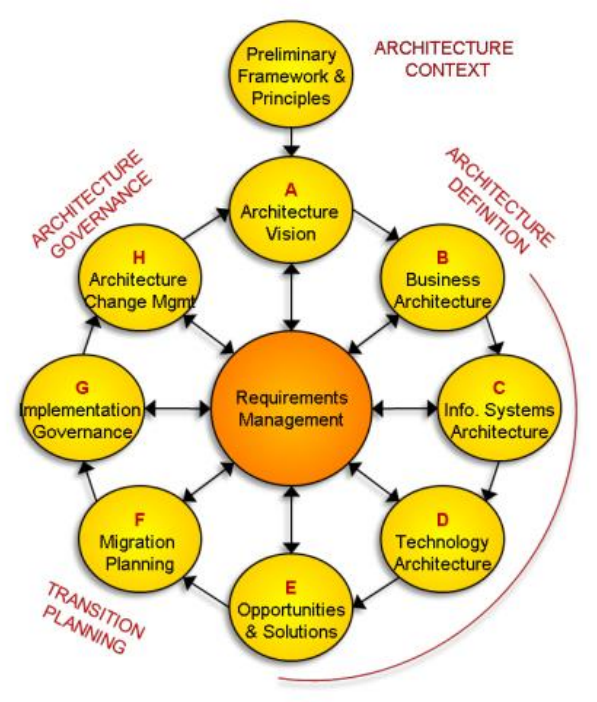

Gambar 2. Komponen Togaf ADM

Pada penelitian ini pendekatan yang digunakan pada Arsitektur Bisnis adalah Bottom-Up,yaitu memulai penelitian dari urutan bawah ke urutan atas dimulai dari Prosedur Operasi Baku/Standar Operasional Prosedur (SOP).

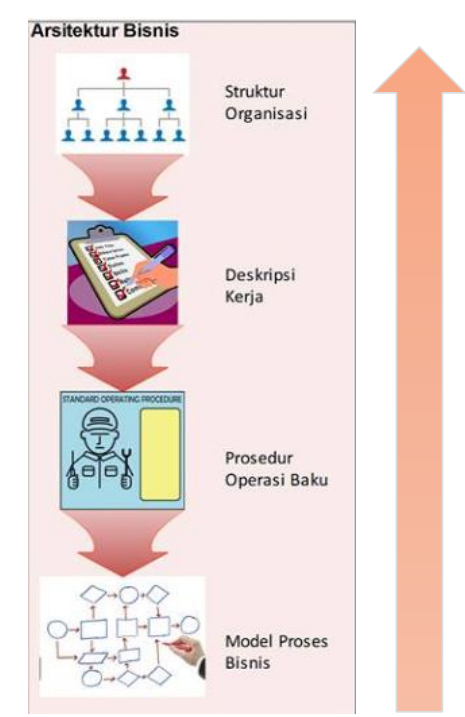

Gambar 3. Bottom up

\section{HASIL DAN PEMBAHASAN}

\subsection{Algoritma TF-IDF}

Prosedur yang dikaji dengan lebih rinci adalah Term Frequency Inverse Document Frequency (TF-IDF). Skema penimbangan ini dapat dikategorikan sebagai prosedur statistik, meskipun hasil langsungnya bersifat deterministik. Meskipun TF-IDF adalah skema penimbangan yang relatif lama, namun sederhana dan efektif, menjadikannya titik awal yang populer untuk algoritma lainnya yang 
Jurnal Riset Sistem Informasi Dan Teknik Informatika (JURASIK)

Volume 5 Nomor 2 Agustus, pp 247-257

ISSN: 2527-5771/EISSN: 2549-7839

https://tunasbangsa.ac.id/ejurnal/index.php/jurasik

lebih baru [6]. Dengan menggunakan Algoritma TF-IDF dapat ditentukan Job Description dari Standar Operasional Prosedur yang telah ditetapkan.

\subsection{Standar Operasional Prosedur}

\section{Berikut adalah penentuan Standar Operasional Prosedur}

Tabel 1. SOP dan Deskripsi

\begin{tabular}{|c|c|c|}
\hline No. & Standar Operasional Prosedur & Deskripsi \\
\hline 1 & $\begin{array}{l}\text { Kepala sekolah memberikan arahan teknis untuk menyusun rencana } \\
\text { kegiatan. }\end{array}$ & Kepala sekolah \\
\hline 2 & Wakasek kurikulum menyusun rencana kegiatan, silabus, dan RPP & Wakasek kurikulum \\
\hline 3 & Guru / MGMP sekolah mengembangkan silabus & Guru mata pelajaran \\
\hline 4 & $\begin{array}{l}\text { Wakasek kurikulum memeriksa draf silabus dan memberikan saran } \\
\text { perbaikan bila diperlukan. }\end{array}$ & Wakasek kurikulum \\
\hline 5 & $\begin{array}{l}\text { Jika ada perbaikan maka guru / MGMP sekolah merumuskan kembali } \\
\text { silabus. }\end{array}$ & Guru mata pelajaran \\
\hline 6 & $\begin{array}{l}\text { Kepala sekolah menyetujui dan menandatangani draf silabuh dan } \\
\text { RPP. }\end{array}$ & Kepala wali kelas \\
\hline 7 & $\begin{array}{l}\text { Draft silabus dan rpp dijadikan sebagai pengangan guru dalam proses } \\
\text { belajar dan mengajar }\end{array}$ & Guru mata pelajaran \\
\hline 8 & $\begin{array}{l}\text { Waka sarana prasarana memaksimalkan kapasitas ruang kelas di } \\
\text { sekolah }\end{array}$ & Waka sarana \\
\hline 9 & Pembangunan kelas baru atau pembatasan murid baru & Pembangunan kelas \\
\hline 10 & Guru membagikan buku teks pelajaran kepada peserta didik. & Guru wali kelas \\
\hline 11 & $\begin{array}{l}\text { Volume dan intonasi suara guru dalam proses pembelajaran harus } \\
\text { dapat didengar dengan baik oleh peserta didik }\end{array}$ & Guru mata pelajaran \\
\hline 12 & $\begin{array}{l}\text { Guru dapat mengajukan pengurangan jumlah kapasitas kelas kepada } \\
\text { waka sarana prasarana }\end{array}$ & Guru mata pelajaran \\
\hline 13 & $\begin{array}{l}\text { Waka sarana prasarana meninjau proses belajar mengajar untuk } \\
\text { dilakukan evaluasi keperluan pengurangan kelas }\end{array}$ & Waka sarana prasarana \\
\hline 14 & Tutur kata guru harus mudah dipahami oleh peserta didik & Guru mata pelajaran \\
\hline 15 & $\begin{array}{l}\text { Guru menyesuaikan materi pembelajaran dengan kecepatan dan } \\
\text { kemampuan belajar peserta didik }\end{array}$ & Guru mata pelajaran \\
\hline 16 & $\begin{array}{l}\text { Guru menciptakan ketertiban, kedisiplinan, keamanan, keselamatan } \\
\text { dan kepatuhan pada peraturan dalam menyelenggarakan proses } \\
\text { belajar mengajar }\end{array}$ & Guru mata pelajaran \\
\hline 17 & $\begin{array}{l}\text { Guru memberikan penguatan dan umpan balik terhadap response } \\
\text { peserta didik selama proses pembelajaran }\end{array}$ & Guru mata pelajaran \\
\hline 18 & $\begin{array}{l}\text { Guru menghargai latar belakang peserta didik tanpa memandang } \\
\text { latar belakang, suku agama, jenis kelamin dan status sosial ekonomi }\end{array}$ & Guru mata pelajaran \\
\hline 21 & $\begin{array}{l}\text { Pada awal semester guru menyampaikan silabus matapelajaran yang } \\
\text { diampunya }\end{array}$ & Guru mata pelajaran \\
\hline 22 & $\begin{array}{l}\text { Guru memulai dan mengakhiri proses pembelajaran sesuai waktu } \\
\text { yang telah dijadwalkan }\end{array}$ & Guru mata pelajaran \\
\hline 23 & $\begin{array}{l}\text { Kepala sekolah melakukan pengawasan sesuai jadwal untuk melihat } \\
\text { proses belajar mengajar }\end{array}$ & Kepala sekolah \\
\hline 26 & Menyusun rencana kegiatan untuk penyusunan perangkat penilaian & Guru mata pelajaran \\
\hline 27 & $\begin{array}{l}\text { Menyusun rambu-rambu mekanisme penyusunan perangkat } \\
\text { penilaian }\end{array}$ & Guru mata pelajaran \\
\hline 28 & Menyusun perangkat penilaian pengetahuan, keterampilan, dan sikap & Guru mata pelajaran \\
\hline 29 & Membahas, melakukan reviu dan revisi perangkat penilaian & Guru mata pelajaran \\
\hline 30 & Mengfinalisasi hasil revisi perangkat penilaian & Guru mata pelajaran \\
\hline 31 & $\begin{array}{l}\text { Validasi dan penandatanganan perangkat penilaian oleh rekan MGMP } \\
\text { sekolah dan kurikulum }\end{array}$ & Guru mata pelajaran \\
\hline 32 & $\begin{array}{l}\text { Menggandakan, mendistribusikan, dan mendokumentasikan } \\
\text { perangkat penilaian }\end{array}$ & Guru mata pelajaran \\
\hline 33 & Melakukan penilaian pencapaian kompetensi peserta didik melalui & Guru mata pelajaran \\
\hline
\end{tabular}


Jurnal Riset Sistem Informasi Dan Teknik Informatika (JURASIK)

Volume 5 Nomor 2 Agustus, pp 247-257

ISSN: 2527-5771/EISSN: 2549-7839

https://tunasbangsa.ac.id/ejurnal/index.php/jurasik

\begin{tabular}{|c|c|c|}
\hline No. & Standar Operasional Prosedur & Deskripsi \\
\hline & UH, UTS, UAS, dan UKK & \\
\hline 34 & Melakukan koreksi lembar jawab hasil ujian/tes & Guru mata pelajaran \\
\hline 35 & $\begin{array}{l}\text { Melakukan pengolahan nilai (UH, UTS, UAS, dan UKK) menggunakan } \\
\text { aplikasi yang telah disediakan oleh kurikulum }\end{array}$ & Guru mata pelajaran \\
\hline 36 & Mengajukan rekap gaji dilampirkan bukti-bukti pendukung & Bendahara \\
\hline 37 & $\begin{array}{l}\text { Bendahara menerima, meneliti, menguji dan menandatangani konsep } \\
\text { SPP-LS berikut berkas pendukung lainnya }\end{array}$ & Bendahara \\
\hline 38 & $\begin{array}{l}\text { Penanda tangan spm menerima, meneliti dan menandatangani SPP- } \\
\text { LS yang kemudian dikembalikan sub bagian daftar gaji }\end{array}$ & Bendahara \\
\hline 39 & $\begin{array}{l}\text { Bendahara melakukan proses penyiapan pengajuan SPP-LS serta } \\
\text { mndokumentasi yang kemudian diteruskan ke penanda tangan SPM }\end{array}$ & Bendahara \\
\hline 40 & $\begin{array}{l}\text { Penjabat pembuat spm menerima, meneliti, memproses dan } \\
\text { membuat SPM }\end{array}$ & Bendahara \\
\hline 41 & $\begin{array}{l}\text { Bendahara menerima, membukukan penerimaan dan pengeluaran } \\
\text { dan menggabungkan berkas dengan SPJ tersebut dengan dokumen } \\
\text { yang ada }\end{array}$ & Bendahara \\
\hline 42 & $\begin{array}{l}\text { Siswa melakukan pembayaran pada batas waktu yang sudah } \\
\text { ditentukan, dengan membawa kartu SPP kepada bagian tu }\end{array}$ & Tata usaha \\
\hline 43 & $\begin{array}{l}\text { Bagian tu akan mencatat setiap pembayaran ke buku transaksi } \\
\text { pembayaran }\end{array}$ & Tata usaha \\
\hline 44 & Bagian tu memberikan stempel tanggal pada kartu SPP siswa & Tata usaha \\
\hline 45 & $\begin{array}{l}\text { Bagian tu mengembalikan kartu SPP kepada siswa, setelah itu } \\
\text { merekap laporan yang kemudian di laporkan kepada kepala sekolah }\end{array}$ & Tata usaha \\
\hline 46 & Mengklasifikasikan sarana dan prasarana yang dibutuhkan & Waka sarana prasarana \\
\hline 47 & Membuat proposal pengadaan sarana dan prasarana & Waka sarana prasarana \\
\hline 48 & $\begin{array}{l}\text { Setelah dikunjungi dan disetujui maka sarana dan prasarana akan } \\
\text { dikirim ke sekolah yang mengajukan permohonan pengadaan }\end{array}$ & Waka sarana prasarana \\
\hline 49 & $\begin{array}{l}\text { Dewan pendidik yang dipimpin oleh kepala sekolah merumuskan visi, } \\
\text { misi, dan tujuan sekolah. }\end{array}$ & Guru mata pelajaran \\
\hline 50 & Kepala sekolah membentuk tim penyusun & Kepala sekolah \\
\hline 51 & $\begin{array}{l}\text { Kepala sekolah melakukan kajian awal mengenai visi, misi, dan tujuan } \\
\text { dengan melibatkan masukan dari komite sekolah }\end{array}$ & Waka kesiswaan \\
\hline 52 & Tim penyusun merumuskan visi, misi, dan tujuan sekolah & Tim wali kelas \\
\hline 55 & Kepala sekolah dan dewan pendidik melakukan reviu dan revisi & Kepala sekolah \\
\hline 57 & Kepala sekolah mensahkan visi, misi, dan tujuan sekolah & Kepala wali kelas \\
\hline 58 & Membuat catatan khusus tentang siswa & Guru wali kelas \\
\hline 59 & Pencatatan mutasi siswa & Guru wali kelas \\
\hline 60 & Mengisi buku laporan penilaian hasil belajar & Guru wali kelas \\
\hline 61 & Pembagian buku laporan hasil belajar & Guru wali kelas \\
\hline 62 & $\begin{array}{l}\text { Kepala sekolah dan dewan pendidik mensosialisasikan visi, misi, dan } \\
\text { tujuan sekolah kepada semua warga sekolah }\end{array}$ & Guru mata pelajaran \\
\hline 63 & Menyusun program dan pelaksanaan bimbingan dan konseling & Guru bk \\
\hline 64 & $\begin{array}{l}\text { Koordinasi dengan wali kelas dalam rangka untuk mengatasi } \\
\text { masalah-masalah yang dihadapi oleh para siswa tentang kesulitan } \\
\text { dalam belajar }\end{array}$ & Guru bk \\
\hline 65 & $\begin{array}{l}\text { Memberikan layanan dan bimbingan kepada siswa supaya lebih } \\
\text { berprestasi dalam kegiatan belajar }\end{array}$ & Guru bk \\
\hline 66 & $\begin{array}{l}\text { Memberikan saran dan pertimbangan kepada siswa dalam } \\
\text { memperoleh gambaran tentang lanjutan pendidikan dan lapangan } \\
\text { pekerjaan yang sesuai }\end{array}$ & Guru bk \\
\hline 68 & Merekap buku yang ada di perpustakaan sekolah & Pustakawan \\
\hline 69 & Melayani peminjaman buku pada siswa & Pustakawan \\
\hline 70 & Melayani administrasi perpustakaan & Pustakawan \\
\hline 71 & Menata koleksi buku & Pustakawan \\
\hline 73 & Mengatur perencanaan pengadaan alat dan bahan di laboratorium & Laboran \\
\hline 74 & Menyusun jadwal dan tata tertib dalam penggunaan laboratorium & Laboran \\
\hline 75 & Mengatur penyimpanan dan daftar alat-alat laboratorium & Laboran \\
\hline
\end{tabular}


Jurnal Riset Sistem Informasi Dan Teknik Informatika (JURASIK)

Volume 5 Nomor 2 Agustus, pp 247-257

ISSN: 2527-5771/EISSN: 2549-7839

https://tunasbangsa.ac.id/ejurnal/index.php/jurasik

\begin{tabular}{|c|l|l|}
\hline No. & \multicolumn{1}{|c|}{ Standar Operasional Prosedur } & \multicolumn{1}{|c|}{ Deskripsi } \\
\hline 76 & Memelihara dan melakukan perbaikan alat-alat laboratorium & Laboran \\
\hline 78 & Menyusun program kerja tata usaha sekolah & Tata usaha \\
\hline 79 & Mengelola keuangan sekolah & Tata usaha \\
\hline 80 & Mengurus administrasi ketenagaan dan siswa & Tata usaha \\
\hline 81 & Pembinaan dan pengembangan karir para pegawai tata usaha sekolah & Tata usaha \\
\hline 82 & $\begin{array}{l}\text { Menyusun laporan pelaksanaan kegiatan pengurusan ketata usahaan } \\
\text { secara berkala }\end{array}$ & Tata usaha \\
\hline 83 & Membina kerjasama dengan masyarakat sekitar sekolah & Waka humas \\
\hline 84 & Membantu pelaksanaan tugas BP3 & Waka humas \\
\hline
\end{tabular}

\subsection{Job Description}

Berikut adalah pembentukan Job Description:

a) Kepala sekolah

1) Menyusun program kerja sekolah.

2) Mengawasi proses belajar mengajar, pelaksanaan dan penilaian terhadap proses dan hasil belajar serta bimbingan dan konseling (BK).

3) Sebagai pembina kesiswaan.

4) Pelaksanaan bimbingan dan penilaian bagi para guru serta tenaga kependidikan lainnya.

5) Penyelenggaraan administrasi sekolah yaitu meliputi administrasi ketenagaan, keuangan, kesiswaan, perlengkapan dan kurikulum.

6) Pelaksanaan hubungan sekolah dengan lingkungan sekitar dan atau masayarakat.

7) Mengetahui dan menandatangani RPP yang dihasilkan

8) Memverifikasi pendataan sarana prasarana

9) Memberi arahan teknis dan menugaskan wakasek kurikulum untuk menyusun rencana kegiatan pembelajaran

b) Kepala TU

1) Menyusun program kerja tata usaha sekolah

2) Mengelola keuangan sekolah

3) Mengurus administrasi ketenagaan dan siswa

4) Pembinaan dan pengembangan karir para pegawai tata usaha sekolah

5) Menyusun laporan pelaksanaan kegiatan pengurusan ketata usahaan secara berkala

c) Wakil kepala sekolah

1) Wakil Kepala Sekolah membantu Kepala Sekolah dalam segala kegiatan di sekolah

2) Menyusun rencana, pembuatan program kegiatan dan program pelaksanaan

3) Pengorganisasian

4) Ketenagakerjaan

5) Pengkoordinasian

6) Penilaian

7) Pengawasan

8) Pengidentifikasi dan pengumpulan data 
d) Wakasek kurikulum

1) Menyusun pembagian tugas para guru.

2) Mengelola semua kegiatan belajar mengajar.

3) Menyusun jadwal evaluasi.

4) Menyusun kriteria untuk kenaikan kelas dan kurikulum.

5) Menyusun pelaksanaan UAS dan UN.

6) Menyusun instrumen untuk kegiatan belajar mengajar.

7) Menyusun kegiatan ekstrakulikuler.

e) Guru/pendidik mata pelajaran

1) Mengembangkan silabus

2) Mengkaji silabus

3) Memperbaiki silabus berdasarkan masukan perbaikan dari wakasek kurikulum

4) Melaksanakan segala hal kegiatan pembelajaran

5) Melaksanakan kegiatan penilaian proses belajar, ulangan (Harian, Umum, dan Akhir)

6) Melaksanakan penilaian dan analisis hasil ulangan harian

7) Melaksanakan program perbaikan dan pengayaan

8) Mengisi daftar nilai siswa

9) Membuat catatan tentang kemajuan dari hasil belajar

10)Mengisi daftar hadir siswa sebelum memulai pelajaran

11)Wakasek kesiswaan

12)Perencanaan dan pelaksanaan kegiatan ekstrakulikuker.

13)Pengadaan pengarahan dan pembina kegiatan OSIS.

14)Penginventarisasian absensi dan pelanggaran-pelanggaran.

15)Penilaian terhadap semua siswa yang mewakili sekolah terhadap kegiatan diluar sekolah.

16)Perencanaan kegiatan setelah siswa lulus

f) Wakasek Sarana Prasarana

1) Mencatat semua alat/barang yang masuk.

2) Mencatat alat laboratorium yang telah masuk.

3) Mencatat alat peraga olahraga.

4) Pengadaan sarana dan prasarana olahraga.

5) Penyusunan aturan anggaran sekolah.

g) Wakasek Hubungan Masyarakat

1) Membina kerjasama dengan masyarakat sekitar sekolah.

2) Membantu pelaksanaan tugas BP3

h) Wali kelas

1) Pengelolaan kelas

2) Penyelenggaraan administrasi kelas meliputi: daftar pelajaran kelas, papan absensi siswa, buku absensi siswa, buku kegiatan pembelajaran/buku kelas, tata tertib siswa

3) Mengisi daftar kumpulan nilai (legger)

4) Membuat catatan khusus tentang siswa

5) Pencatatan mutasi siswa 
6) Mengisi buku laporan penilaian hasil belajar

7) Pembagian buku laporan hasil belajar

i) Bimbingan dan Konseling

1) Menyusun program dan pelaksanaan bimbingan dan konseling

2) Koordinasi dengan wali kelas dalam rangka untuk mengatasi masalahmasalah yang dihadapi oleh para siswa tentang kesulitan dalam belajar

3) Memberikan layanan dan bimbingan kepada siswa supaya lebih berprestasi dalam kegiatan belajar

4) Memberikan saran dan pertimbangan kepada siswa dalam memperoleh gambaran tentang lanjutan pendidikan dan lapangan pekerjaan yang sesuai

j) Pustakawan

1) Merekap buku yang ada di perpustakaan sekolah

2) melayani peminjaman buku pada siswa

3) melayani administrasi perpustakaan

4) menata koleksi buku

k) Laboran

1) Mengatur perencanaan pengadaan alat dan bahan di laboratorium

2) Menyusun jadwal dan tata tertib dalam penggunaan laboratorium

3) Mengatur penyimpanan dan daftar alat-alat laboratorium

4) Memelihara dan melakukan perbaikan alat-alat laboratorium

l) Tata Usaha

1) Menyusun program kerja tata usaha sekolah

2) Mengelola keuangan sekolah

3) Mengurus administrasi ketenagaan dan siswa

4) Pembinaan dan pengembangan karir para pegawai tata usaha sekolah

5) Menyusun laporan pelaksanaan kegiatan pengurusan ketata usahaan secara berkala

\subsection{Struktur Organisasi}

Membentuk Struktur organisasi secara terstruktur yang terbentuk dari hasil analisis semantic

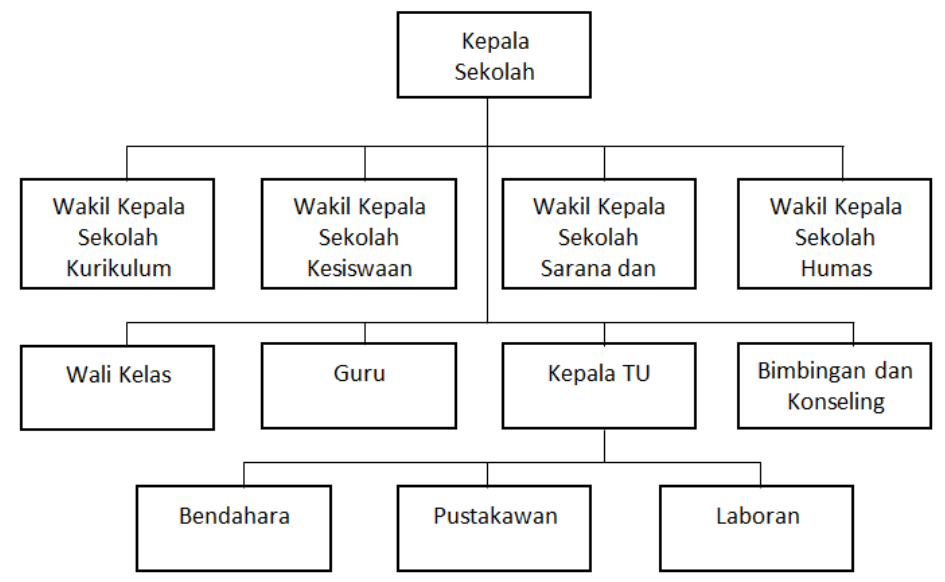

Gambar 4. Struktur Organisasi Sekolah 
https://tunasbangsa.ac.id/ejurnal/index.php/jurasik

\section{SIMPULAN}

Pada penelitian ini, dihasilkan arsitektur bisnis untuk sekolah sesuai dengan standar yang ditetapkan oleh Badan Standar Nasional Pendidikan (BSNP) yaitu Standar Isi, Standar kompetensi Lulusan, Standar Proses Pendidikan, Standar Sarana dan Prasarana, Standar Pengelolaan, Standar Pembiayaan Pendidikan, Standar Penilaian Pendidikan, Standar Pendidik dan Tenaga Kependidikan yang menggunakan metode The Open Group Architecture Framework (TOGAF) fase arsitektur bisnis dengan pendekatan Bottom-Up yang dimulai dengan membuat Standar Operasional Prosedur (SOP) lalu dikelompokkan masing-masing SOP menggunakan algoritma TF-IDF untuk menentukkan Job Description dan membentuk Struktur Organisasi.

\section{DAFTAR PUSTAKA}

[1] Hari Supriyadi and Endang Amalia," Development of Enterprise Architecture in Senior High School Using TOGAF as Framewrok" Universal Journal of Educational Research 7(4A): 8-14, 2019.

[2] Pusat Penjaminan Mutu Pendidikan, "Pedoman Pemenuhan Standar Nasional Pendidikan pada Sekolah Menangah Pertama (SMP)/Madrasah Tsanawiyah (MTs)" , Kementrian Pendidikan dan Kebudayaan, Jakarta, 2012.

[3] Sutrisno, Dedy Prasetya Kristiadi, Dedy Iskandar. 2017. "Pengembangan Arsitektur Enterprise Administrasi SMA Santo Leo 2 Jakarta dengan Metode the Open Group Architecture Framework (TOGAF)". Computer Science STMIK Raharja Tangerang. Incomtech VoL 6, No 1, Juni 2017.

[4] Peraturan Menteri Pendidikan Nasional No.22 Tahun 2006 tentang Standar Nasional Pendidikan pada Sekolah Menangah Pertama (SMP)/Madrasah Tsanawiyah (MTs), Jakarta: Depdiknas.

[5] Hani Irmayanti, Wartika, Imelda. "Pemodelan Arsitektur Enterprise Sekolah Menengah Pertama Negeri 1 Parigi untuk Penerapan Standar Nasional Pendidikan (SNP) Menggunakan TOGAF ADM 9.1". Universitas Komputer Indonesia. Bandung, 2013.

[6] Ramos Juan, "Using TF-IDF to Determine Word Relevance in Document Queries", Department of Computer Science, Rutgers University, 2003. 